\title{
人造肉の消化吸収について
}

\section{Digestibility and Absorption Rate of the Meatless Meat}

国立栄湌研究所 (The National Institute of Nutrition)

$\begin{array}{llllll}\text { 速 } & \text { 水 } & \text { 決 (Hiroshi Hayami) } & \text { 横 田 } & \text { (Fumi Yokota) } \\ \text { 江 指 } & \text { 隆 } & \text { 年 (Takatoshi Esashi) } & \text { 下斗米 敦 子 (Atsuko Shimotomai) } \\ \text { 田 } & \text { 村 由紀子 (Yukiko Tamura) } & \text { 大 山 サカエ (Sakae Oyama) }\end{array}$

To see the digestibility and the absorption rate of the meatless meat, its main constituent is a defatted soybean (Protein 50.65\%, Fat $0.31 \%$, Carbohydrate $29.35 \%$ ), the investigation was made for 12 days by using mature arbino rats with the diet containing $40 \%$ of it.

Then, same rats were given non Protein non Fat diets for 10 days, the endogenous $\mathrm{N}$ in feces was determined. And by using this value, true digestibility and absorption rate of the meatless meat was calculated.

According to the results, apparent absorption rate of this protein is $85.8 \pm 3.4 \%$, and the true one is $89.7 \pm 3.5 \%$. Though, digestibility and absorption rate of Carbohydrate in this diet is 98.4 $\pm 0.4 \%$, digestibility and absorption rate of dextrine which is $80 \%$ of this Carbohydrate is $99.3 \%$, the absorption rate of the Carbohydrate in meatless meat, which correspond to $20 \%$ of the total, is $94.8 \%$.

The absorption rate of Fat $96.3 \%$ is a digestibility and absorption rate of soybean oil which was added to the diet.

\section{I 緒言}

近年, 人造肉とか人工肉とかいわれる食品が造られ, すでにソーセージなどには増量の目的で加えられて市 販されているような状況である。そこでこの人造肉なる物がどれくらい消化吸収されるかをしらべておく必要 があると考える。人造肉にもその製造方法によって幾つかの種類があるようであるが，本実験に用いたものは 脱脂大豆を原料としたテクスグランというものである。その製造については詳しいことはわからないが，製品 の組成はわが研究所で分析したところによれば次のごとくである。

\begin{tabular}{|c|c|c|c|c|c|c|}
\hline 水 & 分 & $10.72 \%$ & 糖 & & 質 & $29.35 \%$ \\
\hline 蛋 白 & 質 & 50.65 & & ン & 1 & 2.73 \\
\hline 皆 & 肪 & 0.31 & 灰 & & 分 & 6.24 \\
\hline
\end{tabular}

食品の消化吸収率を求めるには人体実験によるのが望ましいのであるが，人間ではあまりに極端な献立によ る食事で実験することは実際問題としてむずかしいことである。一方白鼠や犬を用いた実験でも人体実験と大 差ないような成績が得られることでもあり，また急を要するような事情などもあったので，取り敢えず白鼠を 用いて実験を行なった。

な㧍，従来発表されている見掛けの消化吸収率のほかに真の消化吸収率を算出するために，屎中に排泄され る内因性の $\mathrm{N}$ 抢よびエーテル可溶性物質の量を求めるべく, 無蛋白・無脂肪飼料による実験を行ない, さらに 
第 1 表 飼 料 組 成 (\%)

\begin{tabular}{|c|c|c|c|}
\hline & 人造肉飼料 & 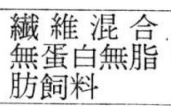 & $\begin{array}{l}\text { 高糖質, 低 } \\
\text { 脂肪, 無蛋 } \\
\text { 白飼料 }\end{array}$ \\
\hline デキストリン & 47 & 94 & 90 \\
\hline 人造肉 & 40 & - & - \\
\hline 大 豆 油 & 10 & - & 6 \\
\hline 混 合 塩 & 2 & 3 & 3 \\
\hline 総合ビタミン & 1 & 1 & 1 \\
\hline 繊 & - & 2 & - \\
\hline
\end{tabular}

デキストリンの消化吸収率を知って人造肉の 糖質の消化吸収率を求めるために，無蛋白・ 低脂肪・高デキストリン飼料による実験を同 一の鼠老用いて行なった。

\section{II 実 験方法}

1. 実験動物：生後 7 カ月ばかりの成熟白 鼠7匹（今 3，古 4) を用いた。

2. 飼料の組成：この人造肉は蛋白質が約

$50 \%$ 含まれているので, 飼料中の蛋白質が $20 \%$ 程度になるように飼料 $100 \mathrm{~g}$ 中に本品を $40 \mathrm{~g}$ 混入することにし た。（第 1 表）

3 . 実験期間：昭和43年 9 月 26 日より10月 8 日までの 12 日間

4. 飼育方法：6室に仕切った金網籠を用い，1匹ずつ入れ，飼料は毎日一定量を科って与え自由食とし， 翌日食べ残しや食べこぼしを科って捸取量を求めた。体重はほとんど毎日測定した。

5. 屎の採集と処理：実験開始時抢よび終了時には, 飼料をカルミンで着色し，それによって屎を区わけし た。屎は毎日集めて乾燥した。屎が湿っているとその表面に飼料の粉末が付着していることが多いが, 乾燥す ると落ち易くなるからブラッシで簡単に除くことができる。また鼠が自身の毛を食べるために，屎塊に毛がさ さったように混入していることがしばしばあるが，乳鉢で粉确し，飾にかけると大部分を除くことができる。 また篩の目を拔けたものでも軽く風を当てると吹き飛ばすことができる。

センイ混合無蛋白・無脂肪飼料には化学実験に用いる沪紙を鋏で刻んで加えたのであるが，屎中には沪紙が 殆んどそのまま出てくるので, 乾燥し乳鉢で搜りつぶしても粉末になりにくい。そこで屎を粉末の部分とセン イの部分にわけて定量することにした。

6. 飼料ならびに康の分析：蛋白質はキエルダール法により $\mathrm{N}$ を求め，N一蛋曰質換算係数は6.25を用いて 粗蛋白とした。脂肋はソックスレー装置により得たエーテル可溶性物質を粗脂肪とし，糖質はベルトラン法に よって求めた。

\section{III 実 験 結 果}

1. 人造肉飼料の攝取量および排泄量 実験開始時の体重は雄は平均 $357 \mathrm{~g}$, 雌は $222 \mathrm{~g}$ であったが，12日後の実験終了時には 雄はいずれも体重の増加を示し, 平均 $17 \mathrm{~g}$ 増 の $374 \mathrm{~g}$ となった。これに対し雌は 4 匹中 1 匹だけ増加したが他の 3 匹はいずれも減少を 示し, 結局平均 $5 \mathrm{~g}$ 減じて $217 \mathrm{~g}$ となった。 第 2 表 飼 料 提 取 量 $(\mathrm{g})$ 12 日間の飼料の摂取量は, 雄は平均 $223 \mathrm{~g}, 1$ 日当り $18.6 \mathrm{~g}$ に対し，雌は平均 $136 \mathrm{~g} ， 1$ 日当り $11.3 \mathrm{~g}$ であった。 蛋白質, 脂肪および糖質の摂取量は第 2 表に示す通りである。 屎の乾燥粉末量は雄では平均 $16.1 \mathrm{~g} 1$ 日当り $1.38 \mathrm{~g}$, 雌では平均 $11.6 \mathrm{~g}, 1$ 日当り $0.97 \mathrm{~g}$ であった。その中 
の粗蛋白，粗脂肪および糖質の量は第 3 表にみる通りである。

\section{2. 七ンイ混合無蛋白・無脂肪飼料実䮖}

人造肉飼料実験後, 6 日間ラット用固形飼料を自由に与えたところ, 白鼠はいずれも体重の増加を示し, 本 実験開始時には雄は平均 $393 \mathrm{~g}$ となった。雌では実験の途中下痢の強かった 1 匹を除くと開始時の 3 匹の平均 体重は $226 \mathrm{~g}$ となる。10日間の飼育によって雄は平均 $56 \mathrm{~g}$, 雌は平均 $31 \mathrm{~g}$ の減少をみた。なお体重 $100 \mathrm{~g}$ 当り の屎中内因性排泄量を求めるために, 実験期間における各々の鼠の体重の中央値を平均すると雄は $364 \mathrm{~g}$, 雌 は $210 \mathrm{~g}$ となる。

屎粒を乾燥して乳鉢で擂りつぶし, 粉末の部分とセンイの部分にわけて, 別々にNおよび粗脂肪を定量し, その和をもって内因性の排泄量とした。体重 $100 \mathrm{~g}$ 当り 1 日の粗蛋白扰よび粗脂肪の排泄量を計算するとそれ

第 3 表 屎中排泄量

\begin{tabular}{|c|c|c|c|c|c|c|c|c|}
\hline \multirow{2}{*}{\multicolumn{2}{|c|}{$\begin{array}{l}\text { 動 物 } \\
\text { 番 号 }\end{array}$}} & \multirow{2}{*}{$\begin{array}{l}\text { 乾燥粉末 } \\
\text { 康量 (g) }\end{array}$} & \multicolumn{2}{|c|}{ 粗 蛋 白 } & \multicolumn{2}{|c|}{ 粗 脂 肪 } & \multicolumn{2}{|c|}{ 粗＼cjkstart糖＼cjkstart質 } \\
\hline & & & $\begin{array}{c}\mathrm{N} \times 6.25 \\
(\%)\end{array}$ & 量 (g) & 含有率 (\%) & 量 $\quad(g)$ & 含有率 (\%) & 量 (g) \\
\hline \multirow[t]{3}{*}{$\hat{o}$} & 1 & 13.63 & 34.39 & 4.69 & 5.70 & 0.78 & 0.86 & 1.18 \\
\hline & 2 & 14.40 & 32.87 & 4.73 & 5.41 & 0.78 & 0.82 & 1.18 \\
\hline & 3 & 21.88 & 33.40 & 7.31 & 4.99 & 1.09 & 0.80 & 1.75 \\
\hline \multirow[t]{4}{*}{ 우 } & 1 & 9.49 & 30.58 & 2.90 & 4.73 & 0.45 & 1.36 & 1.29 \\
\hline & 2 & 12.16 & 32.74 & 3.98 & 4.42 & 0.54 & 1.29 & 1.56 \\
\hline & 3 & 14.24 & 36.67 & 5.22 & 4.53 & 0.65 & 1.05 & 1.50 \\
\hline & 4 & 10.62 & 33.52 & 3.66 & 3.41 & 0.36 & 0.98 & 1.04 \\
\hline
\end{tabular}

第 4 表 無蛋白・無脂肪食期の蛋白質排泄量

\begin{tabular}{|c|c|c|c|c|c|c|c|c|c|}
\hline \multirow{2}{*}{\multicolumn{2}{|c|}{$\begin{array}{l}\text { 動 物 } \\
\text { 番 号 }\end{array}$}} & \multirow{2}{*}{ 屎全量 } & \multicolumn{3}{|c|}{ 粉 末 部 分 } & \multicolumn{3}{|c|}{ 繊 維 部 分 } & \multirow{2}{*}{$\begin{array}{c}\text { 粗 } \begin{array}{c}\text { 蛋 } \\
\text { (mg) }\end{array} \\
\text { 計 }\end{array}$} \\
\hline & & & 重量 $(\mathrm{g})$ & 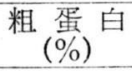 & 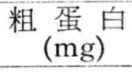 & 重量 (g) & 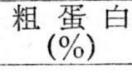 & 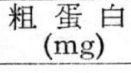 & \\
\hline \multirow{3}{*}{ ô: } & 1 & 11.75 & 2.90 & 21.5 & 621 & 8.85 & 9.2 & 814 & 1,435 \\
\hline & 2 & 11.40 & 2.86 & 25.3 & 723 & 8.54 & 8.5 & 729 & 1,452 \\
\hline & 3 & 10.11 & 1.93 & 22.1 & 426 & 8.18 & 8.5 & 696 & 1,122 \\
\hline \multirow{3}{*}{\multicolumn{2}{|c|}{ 우 $\begin{array}{l}2 \\
3 \\
\\
4\end{array}$}} & 5.95 & 1.54 & 19.7 & 304 & 4.41 & 8.2 & 362 & 666 \\
\hline & & 8.10 & 1.26 & 27.0 & 339 & 6.84 & 7.5 & 510 & 849 \\
\hline & 4 & 8.70 & 2.37 & 23.3 & 551 & 6.33 & 8.5 & 538 & 1,089 \\
\hline
\end{tabular}

第 5 表 無蛋白 ・無脂肪食期の脂肪排泄量

\begin{tabular}{|c|c|c|c|c|c|c|c|c|c|}
\hline \multirow{2}{*}{\multicolumn{2}{|c|}{$\begin{array}{l}\text { 動 物 } \\
\text { 番 号 }\end{array}$}} & \multirow{2}{*}{ 屎全量 } & \multicolumn{3}{|c|}{ 粉末 部 分 } & \multicolumn{3}{|c|}{ 繊 維 部 分 } & \multirow{2}{*}{$\begin{array}{c}\text { 粗 脂 肪 } \\
\text { (mg) } \\
\text { 計 }\end{array}$} \\
\hline & & & 重量 ( g) & $\begin{array}{c}\text { 粗 脂肪 } \\
(\%)\end{array}$ & $\begin{array}{c}\text { 粗 脂 肘 } \\
\text { (mg) }\end{array}$ & 重量 ( g ) & $\begin{array}{c}\text { 粗 脂肪 } \\
(\%)\end{array}$ & $\begin{array}{c}\text { 粗 脂肪 } \\
(\mathrm{mg})\end{array}$ & \\
\hline \multirow{3}{*}{$\begin{array}{ll} & 1 \\
& \\
& \\
& \vdots\end{array}$} & 1 & 11.75 & 2.90 & 5.21 & 151 & 8.85 & 5.14 & 455 & 606 \\
\hline & 2 & 11.40 & 2.86 & 4.54 & 130 & 8.54 & 3.99 & 341 & 471 \\
\hline & 3 & 10.11 & 1.93 & 5.21 & 101 & 8.18 & 8.31 & 680 & 781 \\
\hline \multirow{3}{*}{\multicolumn{2}{|c|}{$\begin{array}{cc}\text { 우 } & 2 \\
& 3 \\
& 4\end{array}$}} & 5.95 & 1.54 & 3.20 & 49 & 4.41 & 3.17 & 140 & 189 \\
\hline & & 8.10 & 1.26 & 2.80 & 35 & 6.84 & 2.67 & 182 & 217 \\
\hline & 4 & 8.70 & 2.37 & 3.58 & 85 & 6.33 & 3.19 & 202 & 287 \\
\hline
\end{tabular}


第 6 表 無蛋白・無脂肪食期の体重の変化と体重 $100 \mathrm{~g}$ 当り 1 日の蛋白および脂肪排泄量

\begin{tabular}{|c|c|c|c|c|c|c|c|c|}
\hline \multirow{2}{*}{\multicolumn{2}{|c|}{$\begin{array}{l}\text { 動 物 } \\
\text { 番 号 }\end{array}$}} & \multicolumn{2}{|c|}{ 体 } & g) & \multicolumn{2}{|c|}{1 日当りの排泄量 (mg) } & \multicolumn{2}{|c|}{$\begin{array}{l}\text { 体重 } 100 \mathrm{~g} \text { 当り } \begin{array}{r}\text { 日の } \\
\text { 排泄量 }\end{array} \\
(\mathrm{mg})\end{array}$} \\
\hline & & 開 始 時 & 終了時 & 期間平均 & 蛋 白 & 脂 & 蛋 白 & 脂 \\
\hline \multirow[t]{3}{*}{$\hat{\delta}$} & 1 & 351 & 302 & 326 & 143.5 & 60.6 & 44.0 & 18.6 \\
\hline & 2 & 377 & 318 & 347 & 145.2 & 47.1 & 41.8 & 13.6 \\
\hline & 3 & 450 & 390 & 420 & 112.2 & 78.1 & 26.7 & 18.6 \\
\hline \multirow[t]{3}{*}{ 우 } & 2 & 209 & 182 & 195 & 66.6 & 18.9 & 34.2 & 9.7 \\
\hline & 3 & 265 & 218 & 242 & 84.9 & 21.7 & 35.1 & 9.0 \\
\hline & 4 & 203 & 184 & 193 & 108.9 & 28.7 & 56.4 & 14.9 \\
\hline 平 & 均 & & & & & & $39.7 \pm 10.1$ & $14.1 \pm 4.2$ \\
\hline
\end{tabular}

ぞれ，39.7士10.1mg および $14.1 \pm 4.2 \mathrm{mg}$ となった。（第 6 表）

3. 高糖質・低脂肪・無蛋白飼料の実験

人造肉飼料には糖質源としてデキストリンが $47 \%$ 加えられていて，飼料中の糖質の約 $80 \%$ を占めているのに 対し，人造肉からの分は僅かに $20 \%$ 程度に過ぎない。そこで第 1 表に示す高糖質・低脂肪・無蛋白飼料により 同一対象の白鼠を 13 日間(昭和 44 年 2 月 25 日より) 飼育しデキストリンの消化吸収率を求めたところ $99.3 \pm 0.14$ \%という值が得られた。（第 7 表）

4. 人造肉飼料の消化吸収率

1) 蛋白質の見掛けの消化吸収率：果中に排泄された粗蛋白はすべて飼料中の蛋白質に由来するものと見做 して見掛けの消化吸収率を求めると $85.8 \pm 3.4 \%$ となった。

2) 蛋白質の真の消化吸収率：人造肉試験期間中为無蛋白・無脂肪飼料実験中と同じうに内因性のNの排 泄があったものとして，10日間の成績から12日分の内因性の粗蛋白量を各例について求め，人造肉蛋白質の真 の消化吸収率を算出したところ平均 $89.7 \pm 3.5 \%$ となり，見掛けより約 $4 \%$ 高い值となった。（第 8 表）

3）脂肪の消化吸収率：本実験に用いた人造肉には僅かに0.31\%脂肪が含まれているに過ぎないのて，この 脂肪の消化吸収率 $96.3 \pm 0.7 \%$ は飼料の脂肪の $99 \%$ を占める大豆油の成績である (第 9 表)。試みに脂肺につ いても真の消化吸収率を求めたところ $99.1 \%$ とった。

4）糖質の消化吸収率：飼料中の糖質の消化吸収率は $98.4 \pm 0.4 \%$ となったが，その糖質の 8 割を占めるデ キストリンの消化吸収率を，高デキストリン飼料実験によって得た $99.3 \%$ とて，20\%に過ぎない人造肉から

第 7 表 デキストリンの消化吸収率

\begin{tabular}{|c|c|c|c|c|c|c|c|c|}
\hline $\begin{array}{l}\text { 動 } \\
\text { 番 }\end{array}$ & 物 & $\begin{array}{c}\text { 飼料摄取量 } \\
(\mathrm{g})\end{array}$ & $\begin{array}{l}\text { 飼料中糖質 } \\
\text { 量 } \\
\text { (g) }\end{array}$ & $\begin{array}{c}\text { 乾燥屎重量 } \\
(\mathrm{g})\end{array}$ & $\begin{array}{l}\text { プルコース } \\
(\mathrm{mg}) \\
\text { 乾燥屎 }(\mathrm{g})\end{array}$ & $\begin{array}{l}\text { 屎中の糖質 } \\
\text { 量 } \quad(g)\end{array}$ & 吸収量 ( g ) & 吸収率 (\%) \\
\hline \multirow[t]{2}{*}{$\hat{\delta}$} & 1 & 220 & 194 & 7.65 & 129 & 0.987 & 193.01 & 99.49 \\
\hline & 2 & 170 & 150 & 7.72 & 149 & 1.150 & 148.85 & 99.23 \\
\hline \multirow[t]{4}{*}{ 우 } & 1 & 171 & 151 & 6.55 & 173 & 1.133 & 149.87 & 99.25 \\
\hline & 2 & 121 & 107 & 4.04 & 230 & 0.929 & 106.07 & 99.13 \\
\hline & 3 & 114 & 100 & 5.39 & 160 & 0.862 & 99.14 & 99.14 \\
\hline & 4 & 125 & 111 & 4.58 & 147 & 0.673 & 110.33 & 99.39 \\
\hline & 均 & & & & & & & $99.3 \pm 0.14$ \\
\hline
\end{tabular}


第 8 表人造肉蛋白質の見掛けの消化吸収率と真の消化吸収率

\begin{tabular}{|c|c|c|c|c|c|c|c|c|}
\hline \multirow{2}{*}{\multicolumn{2}{|c|}{$\begin{array}{l}\text { 動 物 } \\
\text { 番号 }\end{array}$}} & \multirow{2}{*}{$\begin{array}{l}\text { 蛋白質摄 } \\
\text { 取量 }(\mathrm{g}) \\
(19.11 \%)\end{array}$} & \multicolumn{3}{|c|}{ 糜中排泄量 $(\mathrm{g})$} & \multirow{2}{*}{$\begin{array}{c}\text { 吸収実量 } \\
(\mathrm{g})\end{array}$} & \multicolumn{2}{|c|}{ 消化吸収率 (\%) } \\
\hline & & & 総排泄星 & 内因性 & 食餌 性 & & 見掛 & 真 \\
\hline \multirow[t]{3}{*}{$\hat{0}$} & 1 & 40.86 & 4.69 & 1.72 & 2.97 & 37.19 & 88.5 & 92.8 \\
\hline & 2 & 41.18 & 4.73 & 1.74 & 2.99 & 38.19 & 88.5 & 92.7 \\
\hline & 3 & 45.77 & 7.31 & 1.35 & 5.96 & 39.81 & 84.0 & 87.0 \\
\hline \multirow[t]{4}{*}{ 우 } & 1 & 24.86 & 2.90 & 0.92 & 1.98 & 22.88 & 88.3 & 92.0 \\
\hline & 2 & 29.87 & 3.98 & 0.80 & 3.18 & 26.69 & 86.7 & 89.4 \\
\hline & 3 & 24.94 & 5.22 & 1.02 & 4.20 & 20.74 & 79.1 & 83.2 \\
\hline & 4 & 24.37 & 3.66 & 1.31 & 2.29 & 22.08 & 85.2 & 90.6 \\
\hline & 均 & & & & & & $85.8 \pm 3.4$ & $89.7 \pm 3.5$ \\
\hline
\end{tabular}

$\mathrm{N}$-蛋白質換算係数は 6.25

第 9 表人造肉飼料の糖質と脂肪（大豆油）の消化吸収率

\begin{tabular}{|c|c|c|c|c|c|c|c|c|c|c|c|}
\hline \multirow{3}{*}{\multicolumn{2}{|c|}{$\begin{array}{ll}\text { 動 } & \text { 物 } \\
\text { 番 号 }\end{array}$}} & \multicolumn{3}{|c|}{ 摂取量 （g） } & \multicolumn{3}{|c|}{ 排 } & \multicolumn{2}{|l|}{ 量 } & \multicolumn{2}{|c|}{ 消化吸収率 (\%) } \\
\hline & & \multirow{2}{*}{ 飼 料 } & \multirow{2}{*}{$\begin{array}{l}\text { 糖 質 } \\
(52.67 \%)\end{array}$} & \multirow{2}{*}{$\begin{array}{l}\text { 脂 肪 } \\
(10.26 \%)\end{array}$} & \multirow{2}{*}{$\begin{array}{l}\text { 乾燥 } \\
\text { 量 }\end{array}$} & 糖 & 質 & \multicolumn{2}{|c|}{ 粗 脂肪 } & \multirow{2}{*}{ 糖 質 } & \multirow{2}{*}{ 粗脂肪 } \\
\hline & & & & & & $\begin{array}{c}\begin{array}{c}\text { 含有率 } \\
(\%)\end{array} \\
\end{array}$ & 量 ( g ) & $\begin{array}{c}\begin{array}{c}\text { 含有率 } \\
(\%)\end{array} \\
\end{array}$ & 量 $(\mathrm{g})$ & & \\
\hline \multirow[t]{3}{*}{$\hat{\delta}$} & 1 & 213.8 & 112.6 & 21.9 & 13.63 & 0.86 & 1.18 & 5.70 & 0.78 & 98.96 & 96.46 \\
\hline & 2 & 215.5 & 113.5 & 22.1 & 14.40 & 0.82 & 1.18 & 5.41 & 0.78 & 98.96 & 96.48 \\
\hline & 3 & 239.5 & 126.1 & 24.6 & 21.88 & 0.80 & 1.75 & 4.99 & 1.09 & 98.61 & 95.56 \\
\hline \multirow[t]{4}{*}{ 우 } & 1 & 130.1 & 68.5 & 13.4 & 9.49 & 1.36 & 1.29 & 4.73 & 0.45 & 98.11 & 96.63 \\
\hline & 2 & 156.3 & 82.3 & 16.0 & 12.16 & 1.29 & 1.56 & 4.42 & 0.54 & 98.10 & 96.65 \\
\hline & 3 & 130.5 & 68.7 & 13.4 & 14.24 & 1.05 & 1.50 & 4.53 & 0.65 & 97.83 & 95.18 \\
\hline & 4 & 127.5 & 67.2 & 13.1 & 10.62 & 0.98 & 1.04 & 3.41 & 0.36 & 98.45 & 97.23 \\
\hline \multicolumn{2}{|c|}{ 平 均 } & & & & & & & & & \multicolumn{2}{|c|}{$98.4 \pm 0.3896 .3 \pm 0.70$} \\
\hline
\end{tabular}

の糖質の消化吸収率を算出したところ $94.8 \%$ という值が得られた。

\section{IV 考 察}

真の消化吸収率を求めようとして，七ンイ混入無蛋白・無脂肪飼料によって得られた屎の中の内因性の排泄 量を考虑に入れて計算したところ，内因性の排泄量が大きかったために消化吸収率が 100\%を越えるような例 が中にはみられたという報告1)がある。それは10匹の白鼠を用い, 飼料の摂取量を異にする実験を前後 2 回行 なったのであるが，そのうち2〜3の例にそのようなことがみられたのである。本実験では動物の数も少し少 ないが，100\%を超えるような計算值になるものはみられなかった。

人造肉は蛋白源として用いられるわけであるから，その蛋白質の消化吸収率が一番問題である。本品は脱脂 大豆を主な原料として作られたものであるから，大豆その他の豆類の蛋白質の消化吸収率として従来報告され ている $75 \%$ 前後 $(69 \sim 95 \%)$ という值と比較すると, 今回の見掛けの吸収率の $85.8 \pm 3.4 \%$ も真の吸収率の $89.7 \pm 3.5 \%$ もともにかなりよいといえよう。

大西，藤井ら ${ }^{233)}$ は人体実験によって，大豆その他の豆類の真の消化吸収率を求めているがその平均值の $79 \%$ にくらべても本実験の值の方が高かった。（第10表） 
第10表 豆類の消化吸収率 $(\%)$ (大西・藤井ら)

\begin{tabular}{|c|c|c|c|}
\hline & 粗 蛋白 & 粗脂肪 & 粗炭水化物 \\
\hline 八 重 成 & 68.85 & 68.71 & 92.63 \\
\hline ふ じ 豆 & 78.43 & 76.91 & 94.24 \\
\hline さ さ げ & 81.93 & 82.85 & 95.10 \\
\hline 落 花 生 & 95.66 & 92.17 & 95.49 \\
\hline 小＼cjkstart豆 & 76.88 & 77.72 & 98.30 \\
\hline グリンピース & 82.62 & 69.25 & 97.84 \\
\hline そ ら 豆 & 74.30 & 71.76 & 97.91 \\
\hline 大 & 71.44 & 73.46 & 98.10 \\
\hline 大豆納豆 & 81.01 & 82.28 & 97.49 \\
\hline
\end{tabular}

脂肪の消化吸収率 $96.3 \%$ は人造肉に含まれて いる脂肪ではなく，飼料に加えた大豆油の值て あるが，藤井が大豆の消化吸収率をみた時の脂 肪の值の $73.5 \%$ よりは高い。また人造肉飼料の 糖質の消化吸収率は $98.4 \pm 0.4 \%$ となったが， そのうちの 8 割を占めるデキストリンの消化吸 収率を同じ鼠で得た $99.3 \%$ として人造肉中の糖 質の消化吸収率を求めると $94.8 \%$ となる。この 值は藤井の大豆の粗炭水化物の $98.10 \%$ より， また大西, 藤井らの豆類の粗炭水化物の消化吸 収率の平均 $96.3 \%$ より幾分劣ることになる。

これは 1 つには飼料中の糖質の 8 割に当るデキストリンの消化吸収率に $99.3 \%$ という高い值を用いて計算し たことによるものである。因に佐伯，藤本氏 ${ }^{1)}$ らがデキストリンを $66 \%$ に含む標準飼料で白鼠を飼育した際の デキストリンの消化吸収率は93.69～99.20\% で平均 $96.69 \%$ であった。これにくらべと今回の $99.3 \%$ という 值は明らかに高い。

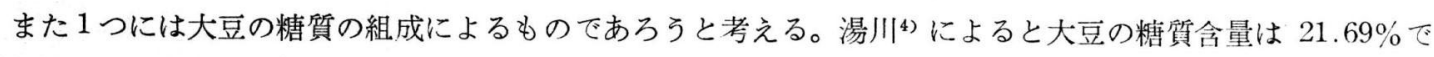

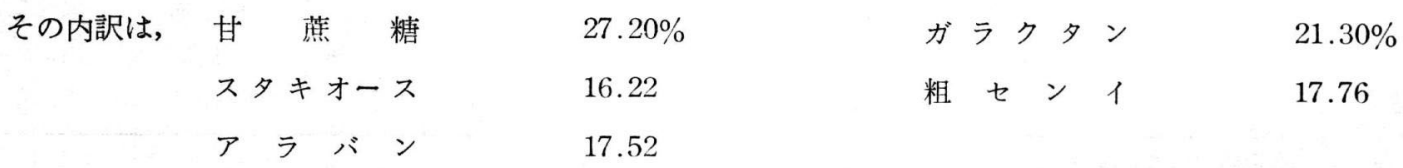

ということであるから，その点を考虑に入れれば， $94.8 \%$ 程度の消化吸収率でよいのではないかと思われる。

\section{総括}

1. 成熟白鼠を用いて，脱脂大豆を原料とする人造肉（テクスグラン）の消化吸収試験を行なったところ， 蛋白質の見掛けの消化吸収率は $85.8 \pm 3.4 \%$ となった。

2. 同一の白鼠を対象とし，無蛋白・無脂肪飼料を与えて屎中に排泄される内因性の損失量を求め, 真の消 化吸収率を算出したところ $89.7 \pm 3.5 \%$ という值が得られた。

3. 本品の脂肪の含量は $0.31 \%$ と著しく低いので, 本実験の脂肪の消化吸収率 $96.3 \pm 0.7 \%$ は飼料に加え た大豆油の消化吸収率である。

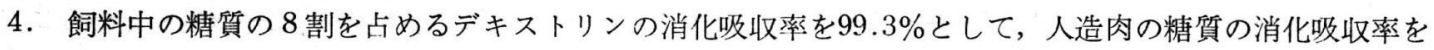
求めると $94.8 \%$ となる。 (本研究は日本曹達KKの依頼試験によるものである。)

文

献

1) 佐伯矩, 藤本櫓喜, 露木貞文: 摂取栄養量と身体機能（その 3 ）摄取栄養量と消化吸収との関係 栄養 研究所報告 10,32-46 (1940)

2) 大西一成: 豆類の消化吸収率に就いて 日本食の研究・第10報 福岡医学会雑誌，44，54-60 (1953)

3）藤井 球：菽䜳類の消化吸収について（II）日本食の研究・第11報 同誌，44，374-381 (1953)

4）湯川又夫：大豆の炭水化物及び其醬油釀造との関係に就て 東京化学会誌, 第38帙, 318-358 (1917) 